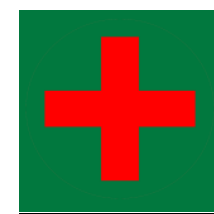

\title{
Hubungan Kedekatan Keluarga dengan Konsep Diri Remaja Putri di Panti Asuhan Al Islam, Sleman, Yogyakarta
}

\author{
Nasiatul Aisyah Salim¹, Antok Nurwidi Antara ${ }^{2}$ \\ ${ }^{1}$ Program Studi Keperawatan, STIKES Wira Husada, Yogyakarta, Indonesia \\ ${ }^{2}$ Program Studi Profesi Ners, STIKES Wira Husada, Yogyakarta, Indonesia \\ Email: ${ }^{1}$ aisyah.salim88@gmail.com
}

\begin{abstract}
Adolescene is a critical period of development. Adolescents face a period of searching for answers to questions about themselves. So that adolescence is an important period in the formation of self concept. Parents are the earliest social contact experienced by a person and the most powerful in the formation of self concept. However, some teenagers are faced with the choice of having to separate from their families and live in orphanages. Several psychological problems are experienced by adolescents who live in orphanages so that it will affect the process of forming adolescent self concepts. This study aims to determine the relationship between the closeness of parents with the self concept of young women with the type of research that is observational analytic with cross sectional study design. The number of samples as many as 18 people with a sampling technique that is total sampling. Sampling using a questionnaire and data analysis using the chi square test. The result of this study indicate that self concept and family closeness in the good category is $61,1 \%$. However, the results of data analysis showed that there was no relationship between family closeness and self concept $(0,24)$. It is hoped that the young women of the orphanage can socialize and easily get along with the environment in order to further increase their self confidence so that their self concept will be better.
\end{abstract}

Keywords: Self Concept; Family; Young Women; Orphanage

\begin{abstract}
Abstrak
Masa remaja merupakan masa perkembangan yang krisis. Remaja menghadapi masa mencari jawaban dari pertanyaan mengenai dirinya. Sehingga masa remaja adalah masa yang penting dalam pembentukan konsep diri. Orang tua adalah kontak social paling awal yang dialami oleh seseorang dan paling kuat dalam pembentukan konsep diri. Namun, beberapa remaja dihadapkan pada pilihan harus berpisah dari keluarga dan tinggal di panti asuhan. Beberapa permasalahan psikologis dialami oleh remaja yang tinggal di panti asuhan sehingga akan berpengaruh terhadap proses pembentukan konsep diri remaja. Penelitian ini bertujuan mengetahui hubungan antara kedekatan orang tua dengan konsep diri remaja putri dengan jenis penelitian yaitu analitik observasional dengan desain cross sectional study. Jumlah sampel sebanyak 18 orang dengan teknik pengambilan sampel yaitu total sampling. Pengambilan sampel menggunakan kuesioner dan analisis data menggunakan uji chi square. Hasil penelitian ini menunjukkan bahwa konsep diri dan kedekatan keluarga pada kategori baik sebesar $61,1 \%$. Namun, hasil analisis data menunjukkan tidak ada hubungan antara kedekatan
\end{abstract}


keluarga dengan konsep diri $(0,24)$. Diharapakan untuk remaja putri panti asuhan dapat bersosialisasi dan mudah bergaul dengan lingkungan agar dapat lebih meningkatkan kepercayaan diri sehingga konsep diri akan semakin baik.

Kata Kunci: Konsep Diri; Keluarga; Remaja Putri, Panti Asuhan

\section{PENDAHULUAN}

Masa remaja merupakan masa perkembangan yang krisis. Remaja menghadapi sense of individual identity yaitu mencari jawaban dari pertanyaan mengenai dirinya (Pieter, 2017). Selain itu, masa remaja dikenal dengan masa storm and stress, dimana terjadi pergolakan emosi yang diiringi dengan pertumbuhan fisik yang pesat dan pertumbuhan psikis yang bervariasi. Oleh karena itu, remaja perlu mengembangkan diri dengan optimal. Salah satu hal penting dalam pengembangan diri remaja adalah pembentukan konsep diri dan masa remaja adalah masa yang penting dalam pembentukan konsep diri.

Konsep diri merupakan gagasan mengenai diri sendiri. Konsep diri merupakan salah satu factor yang mempengaruhi perilaku individu dan dapat mempengaruhi keberhasilan dalam hidup individu (Desmita, 2014). Konsep diri bukan merupakan factor bawaan melainkan berkembang dari pengalaman yang terus menerus. Konsep diri merupakan aspek yang penting dalam diri seseorang karena konsep diri merupakan kerangka acuan dalam berinteraksi dengan lingkungan. Tingkah laku individu yang ditampilkan di lingkungan berpengaruh kuat terhadap konsep diri, karena dengan mengetahui konsep diri akan lebih mudah untuk meramalkan dan memahami perilaku individu (Wulandari, 2016).

Orang tua adalah kontak social paling awal yang dialami oleh seseorang dan paling kuat dalam pembentukan konsep diri. Informasi yang diberikan orang tua akan lebih menancap daripada informasi yang diberikan orang lain dan akan berlangsung hingga dewasa (Santoso, 2014). Menurut Durado dkk, dukungan social dari orang tua dan keluarga sangat berarti dalam memberikan perhatian dan mengarahkan remaja kepada persepsi yang positif terhadap diri sehingga remaja dapat membangun konsep diri yang positif (Durado et al., 2013). Karena keluarga adalah tempat paling awal dan utama untuk berlangsungnya sosialisasi dalam kehidupan bermasyarakat. Nilai dan norma yang dimiliki setiap individu, semua berawal dari lingkungan keluarga (Suwita \& Basri, 2016). Kondisi keluarga yang harmonis dapat berpengaruh terhadap perkembangan remaja.

Namun, beberapa remaja dihadapkan pada pilihan harus berpisah dari keluarganya karena suatu alasan seperti menjadi yatim, piatu atau yatim piatu atau kemiskinan yang mengharuskan hidup terpisah dengan orang tua dan tinggal di panti asuhan. Sehingga remaja tumbuh tanpa kasih sayang orang tua. Akibatnya kebutuhan psikologis anak menjadi kurang dapat terpenuhi dengan baik, terutama jika tidak adanya orang yang dapat dijadikan panutan atau diajak berbagi, bertukar pikiran dalam menyelesaikan masalah (Treanor, 2012). Remaja yang terpisah dari orang tua karena kematian orang tua sangat beresiko mengalami distress (Nyamukapa et al., 2010). 
Tinggal di panti asuhan memiliki perbedaan dengan tinggal di rumah sendiri bersama keluarga yang mana di panti asuhan terdapat tata tertib yang harus dipatuhi oleh semua penghuni panti asuhan tanpa terkecuali. Adanya tata tertib ini seringkali membuat remaja menjadi bosan dan merasa tertekan. Beberapa permasalahan psikologis dialami oleh remaja yang tinggal di panti asuhan disebabkan kebutuhan psikologis yang belum terpenuhi seperti kebutuhan rasa aman, kasih sayang, serta harapan kabur dari masa depannya. Kurangnya pemenuhan kebutuhan emosional serta masalah yang dihadapi oleh remaja dapat mempengaruhi kondisi psikis, serta berpengaruh terhadap proses pembentukan konsep diri remaja yang tinggal di panti asuhan. Sehingga remaja harus berusaha memahami diri sendiri yang merupakan proses penting bagi pembentukan konsep diri.

Perlakuan yang diberikan orang tua, teman sebaya dan pengasuh di panti asuhan sebagai orang terdekat sangat menentukan konsep diri yang berkembang pada remaja. Hal ini karena konsep diri primer dibentuk dalam keluarga, atas dasar kasih sayang dari keluarga maka anak dapat mengembangkan kepercayaan diri. Sedangkan konsep diri sekunder dibentuk di luar rumah melalui pengalaman dengan teman sebaya dan orang lain (Wahyuni, 2012).

Remaja bisa memiliki konsep diri yang cenderung negative karena keberadaannya di panti asuhan dapat menjadi penghambat terbesar dalam perkembangan konsep diri remaja yang mana telah mendapatkan label sebagai orang yang perlu dikasihani. Penelitian Kristianti menunjukkan adanya stress pada remaja yang tinggal di panti asuhan sehingga menyebabkan remaja berperilaku mudah tersinggung, mencari-cari perhatian dari pengurus panti dengan cara berkelahi dengan teman sebayanya, melampiaskan emosi ke orang terdekat dan bertengkar dengan teman (Kristianti, 2013).

\section{METODE}

Penelitian ini merupakan penelitian analitik observasional karena peneliti ingin mengetahui hubungan antara kedekatan keluarga (variable independen) dengan konsep diri (variable dependen) dengan desain cross sectional study. Sampel penelitian ini adalah remaja putri di Panti Asuhan Al Islam sebanyak 18 orang dengan teknik pengambilan sampel menggunakan total sampling. Penelitian dilakukan pada 18 Desember 2020. Pengambilan data dilakukan menggunakan kuesioner. Kuesioner variable kedekatan keluarga berjumlah 5 pertanyaan dan variabel konsep diri berjumlah 5 pertanyaan. Analisis data yang digunakan adalah analisis univariat dan bivariate dengan uji chi square.

\section{HASIL}

A. Karakteristik Responden

Tabel 1. Distribusi Karakteristik Responden di Panti Asuhan Al Islam, Sleman, Yogyakarta

\begin{tabular}{lllc}
\hline Variabel & \multicolumn{1}{c}{ Kategori } & f & Persentase (\%) \\
\hline \multirow{2}{*}{ Umur } & $\leq 17$ tahun & 16 & 88,9 \\
& $>17$ tahun & 2 & 11,1 \\
\hline \multirow{2}{*}{ Kelas } & $\mathrm{X}$ & 4 & 22,2 \\
& $\mathrm{XI}$ & 7 & 38,9
\end{tabular}




\begin{tabular}{llcc} 
& XII & 7 & 38,9 \\
\hline Keberadaan Ayah & Hidup & 17 & 94,4 \\
& Meninggal & 1 & 5,6 \\
\hline Keberadaan Ibu & Hidup & 16 & 88,9 \\
& Meninggal & 2 & 11,1 \\
\hline
\end{tabular}

Tabel 1 menunjukkan bahwa 88,9 \% responden berusia $\leq 17$ tahun, 99,4 \% responden memiliki Ayah yang masih hidup dan 88,9 \% responden memiliki Ibu yang masih hidup.

B. Analisis Univariat

Tabel 2. Persentase Hasil Pertanyaan Variabel Konsep Diri pada Responden di Panti Asuhan Al Islam, Sleman, Yogyakarta

\begin{tabular}{lcccc}
\hline \multicolumn{1}{c}{ Pertanyaan } & $\begin{array}{l}\text { Sangat } \\
\text { Setuju }\end{array}$ & Setuju & $\begin{array}{c}\text { Tidak } \\
\text { Setuju }\end{array}$ & $\begin{array}{c}\text { Sangat } \\
\text { Tidak } \\
\text { Setuju }\end{array}$ \\
\hline Saya orang yang percaya diri & 22,2 & 50,0 & 27,8 & 0 \\
\hline Saya takut gagal & 11,1 & 38,9 & 50,0 & 0 \\
\hline $\begin{array}{l}\text { Saya popular di kalangan } \\
\text { perempuan }\end{array}$ & 0 & 27,8 & 66,7 & 5,6 \\
\hline Saya tidak pintar dalam bergaul & 5,6 & 44,4 & 27,8 & 22,2 \\
\hline $\begin{array}{l}\text { Saya merasa sulit untuk dekat } \\
\text { dengan orang lain }\end{array}$ & 16,7 & 33,3 & 33,3 & 16,7 \\
$\begin{array}{l}\text { Tabel 2 menunjukkan bahwa 50 \% responden adalah orang yang percaya diri, 50 } \\
\% \text { responden tidak takut gagal, 66,7 \% responden tidak popular di kalangan } \\
\text { perempuan, 44,4 \% responden tidak pintar dalam bergaul dan 33,3 \% responden } \\
\text { merasa sulit untuk dekat dengan orang lain. }\end{array}$ & & &
\end{tabular}

Tabel 3. Persentase Hasil Pertanyaan Variabel Kedekatan Keluarga pada Responden di Panti Asuhan Al Islam, Sleman, Yogyakarta

\begin{tabular}{lcccc}
\hline \multicolumn{1}{c}{ Pertanyaan } & $\begin{array}{c}\text { Sangat } \\
\text { Setuju }\end{array}$ & Setuju & $\begin{array}{c}\text { Tidak } \\
\text { Setuju }\end{array}$ & $\begin{array}{c}\text { Sangat } \\
\text { Tidak } \\
\text { Setuju }\end{array}$ \\
\hline $\begin{array}{l}\text { Saya memiliki keluarga yang } \\
\text { selalu siap membantu ketika } \\
\text { saya dalam keadaan sulit }\end{array}$ & 61,1 & 33,3 & 5,6 & 0 \\
\hline $\begin{array}{l}\text { Saya berasal dari keluarga yang } \\
\text { bahagia }\end{array}$ & 66,7 & 33,3 & 0 & 0 \\
\hline $\begin{array}{l}\text { Saya tidak dicintai oleh keluarga } \\
\text { saya }\end{array}$ & 0 & 0 & 11,1 & 88,9 \\
\hline $\begin{array}{l}\text { Saya puas tentang hubungan } \\
\text { saya dengan keluarga saya }\end{array}$ & 55,6 & 33,3 & 11,1 & 0 \\
\hline $\begin{array}{l}\text { Saya sering bertengkar dengan } \\
\text { keluarga saya }\end{array}$ & 0 & 5,6 & 33,3 & 61,1 \\
\hline
\end{tabular}

Tabel 3 menunjukkan bahwa 61,1 \% responden memiliki keluarga yang siap membantu bila responden dalam keadaan sulit, 66,7 \% responden berasal dari keluarga yang bahagia, 88,9 \% responden dicintai oleh keluarga, 55,6 \% 
responden puas dengan hubungan bersama keluarga, 61,1\% responden tidak sering bertengkar dengan keluarga.

Tabel 4. Distribusi Variabel Kedekatan Keluarga dan Konsep Diri Responden di Panti Asuhan Al Islam, Sleman, Yogyakarta

\begin{tabular}{clcc}
\hline Variabel & Kategori & f & Persentase (\%) \\
\hline Konsep Diri & Positif & 11 & 61,1 \\
& Negatif & 7 & 38,9 \\
\hline Kedekatan Keluarga & Baik & 11 & 61,1 \\
& Tidak Baik & 7 & 38,9 \\
\hline
\end{tabular}

Tabel 4 menunjukkan bahwa 61,1\% responden memiliki konsep diri yang positif dan $61,1 \%$ responden memiliki kedekatan keluarga yang baik.

C. Analisis Bivariat

Tabel 5. Hubungan Kedekatan Keluarga dengan Konsep Diri pada Responden di Panti Asuhan Al Islam, Sleman, Yogyakarta

\begin{tabular}{lcccc}
\hline \multirow{2}{*}{$\begin{array}{l}\text { Kedekatan } \\
\text { Keluarga }\end{array}$} & \multicolumn{2}{c}{ Konsep Diri } & Total & p \\
\cline { 2 - 3 } Tidak Baik & Negatif & Positif & & \\
Baik & $5(71,4 \%)$ & $2(28,6 \%)$ & $7(100 \%)$ & 0,24 \\
\hline
\end{tabular}

Tabel 5. Menunjukkan bahwa 81,9 \% responden memiliki konsep diri dan kedekatan keluarga yang baik. Hasil uji chi-square diperoleh nilai signifikan 0,24 $>0,05$ menunjukkan tidak ada hubungan kedekatan keluarga dengan konsep diri pada remaja putri di Panti Asuhan Al Islam, Sleman, Yogyakarta.

\section{PEMBAHASAN}

Hasil penelitian ini menjelaskan bahwa $61,1 \%$ responden memiliki konsep diri yang positif. Hal ini terlihat $50 \%$ responden memiliki kepercayaan diri, $50 \%$ responden tidak takut gagal. Sehingga hasil penelitian ini sejalan dengan Gunarsa yang menyatakan remaja yang konsep dirinya berkembang dengan baik akan tumbuh rasa percaya diri, berani, bersemangat dalam belajar, memiliki keyakinan diri, aktif dalam belajar, menjadi pribadi yang mandiri dan memiliki pandangan yang baik tentang dirinya (Gunarsa, 2008). Menurut Ayu R, menjelaskan bahwa ada hubungan positif antara konsep diri dengan kepercayaan diri pada remaja putri panti asuhan (Retnowati, 2018).

Hasil penelitian ini juga menjelaskan $66,7 \%$ responden tidak popular di kalangan perempuan, $44,4 \%$ responden tidak pintar dalam bergaul dan $33,3 \%$ responden merasa sulit untuk dekat dengan orang lain. Hal ini seperti yang dijelaskan Hartiyani bahwa anak yang tinggal di panti asuhan mengalami masalah psikologis dengan karakteristik diantaranya kepribadian yang inferior, pasif, bersikap apatis, menarik diri, mudah putus asa, penuh ketakutan dan kecemasan. Selain itu juga menunjukkan perilaku yang negativistis takut untuk melakukan kontak dengan orang lain, lebih menyukai sendirian dan lebih egosentrisme sehingga akan sulit menjalin hubungan social dengan orang lain 
(Hartiyani, 2011). Di sisi lain, remaja panti memiliki sikap kemandirian yang cukup tinggi karena telah ditanamkan sejak dini untuk tidak bergantung dengan orang lain.

Hasil penelitian ini juga menjelaskan bahwa $61,1 \%$ responden memiliki kedekatan keluarga yang baik. Hal ini terlihat $88,9-94,4 \%$ responden memiliki ayah dan ibu yang masih hidup. Sehingga terlihat $61,1 \%$ responden merasa memiliki keluarga yang siap membantu bila responden dalam keadaan sulit, 66,7 \% responden berasal dari keluarga yang bahagia, 88,9\% responden dicintai oleh keluarga, 55,6\% responden puas dengan hubungan bersama keluarga, 61,1 \% responden tidak sering bertengkar dengan keluarga.

Meskipun hasil penelitian ini menunjukkan konsep diri dan kedekatan keluarga yang baik namun dari hasil uji statistic chi square menunjukkan tidak ada hubungan antara kedekatan keluarga dengan konsep diri remaja di Panti Asuhan Al Islam Sleman, Yogyakarta. Hal ini kemungkinan karena ada factor lain yang berhubungan dengan konsep diri remaja putri di Panti Asuhan Al Islam Sleman, Yogyakarta seperti penerimaan diri, kecerdasan emosi, optimisme, kedekatan dengan orang tua asuh di Panti Asuhan, teman sebaya,.

Masa remaja merupakan masa pembentukan konsep diri, sehingga dibutuhkan proses penerimaan diri untuk mencapai konsep diri yang positif. Orang yang memiliki penerimaan diri yang baik maka dapat dikatakan memiliki konsep diri yang baik pula karena selalu mengacu pada gambaran diri ideal sehingga bisa menerima gambaran dirinya sesuai dengan realita (Herumaningsih, 2020). Remaja panti yang memiliki penerimaan diri yang tinggi dapat lebih realistis menerima segala bentuk kekurangan maupun kelebihan di dalam diri (Bernard, 2014).

Konsep diri yang baik akan menjadikan remaja sehat secara emosi dan hal ini akan berdampak baik bagi kematangan emosi sehingga remaja akan memperoleh kecerdasan emosi yang tinggi (Salam, 2011). Menurut hasil penelitian Muliani et al, ada hubungan yang berarti antara kecerdasan emosi dengan tingkat konsep diri pada remaja. Penelitian yang sama juga dijelaskan Putri \& Alfiasari bahwa konsep diri remaja panti asuhan berhubungan positif dengan kecerdasan emosi. Jadi remaja yang matang emosinya adalah remaja yang konsep dirinya berkembang baik (Qashdina \& Alfiasari, 2019).

Menurut Kurniawan dkk menemukan bahwa konsep diri berhubungan positif dengan optimisme (Kurniawan et al., 2015). Selain itu, Abdi dkk juga menemukan bahwa ada pengaruh kebersyukuran dan konsep diri terhadap optimisme (Wahid et al., 2018). Penelitian Nashori menunjukkan bahwa salah satu karakter remaja yang berbeda dengan karakter orang dewasa adalah optimisme. Orang muda memiliki optimisme yang lebih tinggi dibanding orang dewasa (Nashori, 2011). Optimisme akan mempengaruhi regulasi diri untuk mencapai tujuan dan berusaha yang besar ketika menghadapi hambatan. Individu dengan optimisme yang tinggi memiliki moral yang baik, motivasi, prestasi, kondisi kesehatan yang baik dan dapat mengatasi masalah (Chang \& McBride-Chang, 1996). Menurut Hutz, perkembangan optimisme dalam diri individu dipengaruhi oleh pengasuhan orang tua (Zanon et al., 2014).

Menurut Fitts, konsep diri dipengaruhi oleh pengalaman interpersonal remaja dengan orang tua dan signicant other. Remaja yang memiliki perasaan positif dan berharga dalam berinteraksi dengan significant other akan mengarahkan remaja 
memiliki konsep diri yang positif. Orangtua asuh dan teman di Panti Asuhan adalah keluarga pengganti bagi remaja. Remaja di Panti Asuhan yang memiliki kedekatan dengan orang tua asuh akan cenderung menilai orang tua asuh secara positif. Oleh karena itu, kedekatan antara remaja panti asuhan dengan orang tua asuh dan teman sebaya akan berpengaruh terhadap konsep dirinya (Fitts, 1971). Sehingga sangat penting peran dan dukungan orang tua asuh panti dalam pembentukan kepribadian diri remaja panti yang diasuhnya.

Menurut Dika \& Dian menjelaskan ada hubungan positif antara dukungan teman sebaya dengan konsep diri pada remaja Panti Asuhan (Ananda \& Sawitri, 2015). Remaja panti asuhan dalam kesehariannya lebih banyak menghabiskan waktu dengan teman sebaya sehingga umpan balik akan lebih banyak diperoleh melalui teman sebaya pula. Begitupun kondisi remaja panti asuhan yang tidak tinggal bersama orang tua, membuat teman sebaya di dalam maupun di luar panti asuhan dimungkinkan memiliki pengaruh yang lebih besar terhadap perkembangan konsep diri.

Menurut Rukmini menjelaskan bahwa ada hubungan konsep diri dengan perkembangan remaja di Panti Asuhan (Rukmini, 2018). Perkembangan adalah perubahan yang dialami individu menuju tingkat kedewasaan yang berlangsung secara sistematis, progresif dan berkesinambungan menyangkut fisik maupun psikis. Sedangkan perkembangan konsep diri ditentukan cara remaja menginterpretasikan perlakuan orang lain. Menurut Ali \& Asrori, ada lima karakteristik perkembangan remaja yaitu kegelisahan, pertentangan, mengkhayal, aktivitas kelompok dalam masa remaja, keinginan mencoba segala sesuatu (Asrori, 2011).

Menurut Assahhra, factor yang mempengaruhi konsep diri positif adalah penerimaan dan kehangatan dari lingkungan, factor social dan proses belajar dimana individu harus dapat bersosialisasi dengan baik di lingkungan panti asuhan maupun di luar seperti sekolah dan menggunakan pengalaman sebagai suatu pembelajaran yang membuat individu berikir lebih positif (Assahhra, 2012). Menurut Pusparini \& Masukur, konsep diri yang baik dipengaruhi oleh factor lingkungan dan keterbukaan (Pusparini A \& Masukur, A, 2014). Lingkungan panti asuhan menjadi lingkungan social yang utama dalam membentuk penyesuaian diri remaja.

\section{KESIMPULAN DAN SARAN}

Berdasarkan hasil penelitian dan pembahasan yang telah diuraikan dapat disimpulkan bahwa tidak ada hubungan kedekatan keluarga dengan konsep diri pada remaja putri di Panti Asuhan Al Islam, Sleman, Yogyakarta. Diharapkan kepada remaja putri Panti Asuhan Al Islam belajar untuk bersosialisasi dan mudah dekat dengan orang lain dan kepada orang tua remaja putri panti Asuhan Al Islam dapat meningkatkan memberikan perhatian dan kasih sayang ketika remaja putri pulang ke rumah.

\section{DAFTAR PUSTAKA}

Ananda, D. R. T., \& Sawitri, D. R. (2015). Konsep diri ditinjau dari dukungan teman sebaya pada remaja di panti asuhan qosim al-hadi semarang. Jurnal Empati, 4(4), 
298-303.

Asrori, A. \&. (2011). Psikologi Remaja. Bumi Aksara.

Assahhra, M. F. (2012). Konsep diri remaja yang tinggal di panti asuhan (Studi kasus). E-Journal Psikologi, 1-13.

Bernard, M. E. (2014). The strength of self-acceptance: Theory, practice and research. Springer.

Chang, L., \& McBride-Chang, C. (1996). The factor structure of the Life Orientation Test. Educational and Psychological Measurement, 56(2), 325-329.

Desmita. (2014). Psikologi Perkembangan Peserta Didik. Rosdakarya.

Durado, A. A., Tololiu, T. A., \& Pangemanan, D. H. C. (2013). Hubungan dukungan orang tua dengan konsep diri pada remaja di SMA Negeri 1 Manado. Jurnal Keperawatan, 1(1). https://doi.org/10.35790/jkp.v1i1.2163

Fitts, W. H. (1971). The self-concept and self-actualization. Studies on the Self Concept. Gunarsa, S. D. (2008). Psikologi perkembangan anak dan remaja. BPK Gunung Mulia. Hartiyani, N. (2011). Hubungan Konsep Diri dan Kepercayaan Diri dengan Interaksi Sosial Remaja Panti Asuhan Nur Hidayah Surakarta.

Herumaningsih, H. (2020). Meningkatkan Penerimaan Diri (Self Acceptance) siswa kelas VIII melalui Konseling Realita di SMP Negeri 1 Gatak Kabupaten Sukoharjo Tahun Pelajaran 2016/2017. Jurnal Pendidikan Payan Mas, 4(2), 59-70.

Kristianti. (2013). Stress pada Remaja yang Tinggal di Panti Asuhan. Psikologi, 01, $566-580$.

Kurniawan, S., Priyatama, A. N., \& Karyanta, N. A. (2015). Hubungan konsep diri dengan optimisme dalam menyelesaikan skripsi pada mahasiswa prodi psikologi fakultas kedokteran UNS. Jurnal Ilmiah Psikologi Candrajiwa, 3(4 Mar).

Nashori, F. (2011). Kekuatan karakter santri. Millah: Jurnal Studi Agama, 11(1), 203219.

Nyamukapa, C. A., Gregson, S., Wambe, M., Mushore, P., Lopman, B., Mupambireyi, Z., Nhongo, K., \& Jukes, M. C. H. (2010). Causes and consequences of psychological distress among orphans in eastern Zimbabwe. AIDS Care, 22(8), 988-996.

Pieter, H. Z. (2017). Pengantar psikologi dalam keperawatan. Kencana.

Pusparini A \& Masukur, A, M. (2014). Hubungan Konsep Diri dengan Asertivitas di kelas X SMA Kesatrian 2 Semarang.

Qashdina, P. D., \& Alfiasari, A. (2019). Pentingnya Peran Kelekatan Teman Sebaya Dalam Konsep Diri dan Kecerdasan Emosi Remaja di Panti Asuhan di Kota Banda Aceh. Jurnal Penelitian Kesejahteraan Sosial, 17(4), 351-364.

Retnowati, A. (2018). Hubungan Konsep Diri dengan Kepercayaan Diri Remaja Panti Asuhan Al-Jamia'Yatul Washliyah (Pulo Brayan). Universitas Medan Area.

Rukmini, R. (2018). Konsep Diri dan Perkembangan Remaja di Panti Asuhan "Hasyim Asy'ari" Sidoarjo. Jurnal Ners LENTERA, 6(2), 165-169.

Salam, S. \& A. (2011). Hubungan Dukungan Keluarga dengan Konsep Diri Remaja Kelas VIII SMPN 13 Depok, Sleman, Yogyakarta. 1(1).

Santoso. (2014). Manajemen Panti Asuhan. Rineka Cipta.

Suwita, P., \& Basri, B. (2016). Tingkat Penyesuaian Diri Anak Yang Tinggal di Panti Asuhan (Studi pada Panti Asuhan Baiturrahmah Desa Rimbo Panjang Km. 17 Kecamatan Tambang Kabupaten Kampar). Riau University.

Treanor, M. (2012). Impacts of poverty on children and young people. Scottish Child Care and Protection Network (SCCPN).

Wahid, A. W., Larasati, A., Ayuni, A., \& Nashori, F. (2018). Optimisme Remaja yang Tinggal di Panti Asuhan Ditinjau dari Kebersyukuran dan Konsep Diri. 
Humanitas: Jurnal Psikologi Indonesia, 15(2), 267229.

http://dx.doi.org/10.26555/humanitas.v15i2.8725

Wahyuni, S. \&. (2012). Psikologi Keperawatan. PT. Raja Grafindo Persada.

Wulandari. (2016). Peran Penerimaan Diri dan Dukungan Sosial terhadap Konsep Diri Remaja yang Tinggal di Panti Asuhan di Bali. Psikologi Udayana, 3(3), 509-518.

Zanon, C., Bastianello, M. R., Pacico, J. C., \& Hutz, C. S. (2014). The importance of personality and parental styles on optimism in adolescents. The Spanish Journal of Psychology, 17. 